\title{
CONTINUOUS SHARPENING OF HÖLDER'S AND MINKOWSKI'S INEQUALITIES
}

\author{
S. Abramovich, J. PeČARIĆ AND S. VAROŠANEC
}

Abstract. Some properties of functions which in special cases lead to sharpening of Hölder's and other interesting inequalities are proved. Results analogue to theorems leading to reverse Hölder's inequality are presented.

Mathematics subject classification (2000): 26A48, 26D10.

Key words and phrases: Inequalities, Hölder's Inequality, Minkowski's Inequality.

\section{REFERENCES}

[1] Abramovich, S., J. E. PeČARIĆ Convex and concave function and generalized Hölder's inequalities, Soochow J. Math., 24, (1998), 261-272.

[2] PEČARIĆ, J. E. AND P. R. BEESACK On Jessen's inequality for convex functions II. J. Math. Anal. Appl., 118, (1986), 125-144.

[3] PeČarić, J. E., Proschan, F. And Y. L. Tong, Convex Functions, Partial Orderings and Statistical Applications, San Diego (USA), Acad. Press Inc. 1992.

[4] YANG, X., A generalization of Hölder's inequality, J. Math. Anal. Appl., 247, (2000), 328-300. 